\title{
THE HISTORY OF ANNUITIES
}

IN THE UNITED STATES

James M. Poterba

Working Paper 6001

\section{NATIONAL BUREAU OF ECONOMIC RESEARCH 1050 Massachusetts Avenue \\ Cambridge, MA 02138 \\ April 1997}

\begin{abstract}
I am grateful to Michael Boskin, William Gentry, Harry Klaristenfeld, and Paul Tattersall for very helpful comments on an earlier draft, and to the Catalyst Institute for research support. This paper is part of a Catalyst Institute project on "Annuities: The Private Retirement Alternative." This paper is part of NBER's research programs in Aging, Asset Pricing, Corporate Finance and Public Economics. Any opinions expressed are those of the author and not those of the National Bureau of Economic Research.
\end{abstract}

(C) 1997 by James M. Poterba. All rights reserved. Short sections of text, not to exceed two paragraphs, may be quoted without explicit permission provided that full credit, including $\mathbb{C}$ notice, is given to the source. 
The History of Annuities in the United States

James M. Poterba

NBER Working Paper No. 6001

April 1997

JEL Nos. G22, D91

Aging, Asset Pricing, Corporate Finance

and Public Economics

ABSTRACT
This paper summarizes the development of private annuity markets in the United States.

Annuities constituted a small share of the U.S. insurance market until the 1930s, when two developments contributed to their growth. First, concerns about the stability of the financial system drove investors to products offered by insurance companies, which were perceived to be stable institutions. Flexible payment deferred annuities, which permit investors to save and accumulate assets as well as draw down principal, grew rapidly in this period. Second, the group annuity market for corporate pension plans began to develop in the 1930s. The group annuity market grew more rapidly than the individual annuity market for several decades after World War II. The most recent development in the annuity marketplace has been the rapid expansion of variable annuities. These annuity products combine the investment features of mutual funds with the tax deferral available for life insurance products. Variable annuity premium payments increased by a factor of five in the most recent five years for which data are available.

James M. Poterba

Department of Economics

Massachusetts Institute of Technology

Room E52-350

50 Memorial Drive

Cambridge, MA 02139-4307

and NBER

poterba@mit.edu 


\section{Introduction to Annuities}

Annuities are contracts that provide periodic payments for an agreed-upon span of time. They include annuities certain, which provide periodic payouts for a fixed number of years, and life annuities, which provide such payouts for the duration of one or more persons' (the annuitants') lives. The principal insurance role of annuities is to indemnify individuals against the risk of outliving their resources.

Consider the choices confronting a retiree who has accumulated assets by saving over time, through inheritance, or as a result of company contributions to a pension plan. Assume that he expects no future income other than the return on his capital and that he has no desire to leave a bequest. How should this individual deplete his assets each year? If he knew for certain how long he would live, this retiree could compute the time profile of consumption that would just exhaust his wealth when he died. But the fact that the individual does not know his date of death complicates the choice of a consumption profile. If he consumes relatively little in the first few years of retirement, he will make adequate provision for a very long life. There is a chance, however, that he will die with a large sum of remaining capital. Alternatively, if the individual consumes aggressively in the near term, the prospect looms of having to reduce consumption later if he lives longer than expected.

Annuities solve the retiree's consumption problem. In return for an initial capital payment, he is assured of receiving a constant income stream for the remainder of his life. The annuity provider can pool mortality risk across similar individuals and thereby can, with the principal left behind by those who died sooner than expected, insure those who live unexpectedly long. As a result, the annuitant's payout from the annuity contract can, in theory, exceed what he could earn if he invested the amount of his annuity premium and then consumed only the income flow.

The annuity payout rate rises based on the annuitant's prospective mortality risk and 
on the rate of return that the annuity provider can earn on invested assets. Younger individuals, because they are expected to receive payments for a longer time period, receive lower annuity payouts than older annuitants do for a given amount of capital invested. Higher rates of return generate greater income per dollar of capital and also make possible the offering of higher payout rates to annuitants. As an example of an annuity contract, consider a 65-year-old man who plans to spend $\$ 100,000$ to purchase an immediate life annuity. The Annuity and Life Insurance Shopper (April-June 1995, 13) reports the payouts on immediate annuities offered by a number of insurance companies. These range from $\$ 727$ per month $(\$ 8,724$ per year) to $\$ 908$ per month $(\$ 10,896$ per year); this illustrates both the typical payout level on annuities and the substantial disparity in annuity terms across different providers. For a 65 -year-old woman, the annuity payout per $\$ 100,000$ investment ranges from $\$ 638$ per month to $\$ 833$ per month. Her lower payout reflects the greater life expectancy for women than for men.

Annuities are sometimes referred to as "reverse life insurance." With life insurance, the policyholder pays the insurer each year until he or she dies, after which the insurance company pays a lump sum to the insured's beneficiaries. With annuities, the lump-sum payment is from the annuitant to the insurance company before the annuity payout begins, and the annuitant receives regular payouts from the insurer until death.

Most annuity contracts have an accumulation phase and a liquidation phase. During the accumulation phase, capital builds up; this capital is dispersed during the liquidation phase. In the case of the single-premium immediate annuity considered above, there is no accumulation phase. Annuitants make lump-sum payments of the accumulated capital that they wish to draw down to the annuity provider. During the liquidation phase, the annuitants receive payouts contingent upon their survival or in accord with other terms specified in the 
annuity contract. In many annuity contracts, payouts are specified as a guaranteed minimum, with the opportunity for a dividend if mortality experience or rates of return on insurance company investments prove better than expected.

Many annuity products exhibit long accumulation phases, so they operate in part as saving vehicles. Although annuities are unique in their provision of income streams contingent on remaining alive, they compete with other financial products as a means for asset accumulation.

Annuities have historically been offered by insurance companies, which pool the mortality risk across many individuals and thereby achieve a more predictable cash flow than if they offered an annuity to only one individual. The same principles that underpin risk reduction in life insurance sales apply to the provision of annuity payouts. The annuity supplier must have sufficient capital and be sufficiently long-lived to ensure that annuity payouts will still be paid if the annuitant lives for many years. One of the current regulatory battles in the United States concerns whether banks and other financial institutions that provide saving vehicles should be permitted to underwrite annuities. A key question is whether any entity which sells annuities or assumes a mortality risk with respect to annuities should be subject to state insurance department scrutiny.

\subsection{Annuities and the Value of Insurance}

Annuities can make consumers better off by providing insurance against the possibility of reaching extreme old age with very low remaining financial resources. To illustrate this proposition, Kotlikoff and Spivak (1981) calculate the gain in lifetime utility for a 30-year-old man who faces mortality risk and can purchase an actuarially fair annuity, one for which the expected discounted value of annuity payouts equals the purchase price of the annuity. The utility gain from purchasing an annuity on these terms is equivalent to the utility gain from a 
30 percent increase in the present discounted value of his lifetime earnings. The utility gains are even larger for older individuals, for whom uncertain longevity represents a more immediate source of risk.

Friedman and Warshawsky (1988) contrast the consumption profiles that individuals with and without access to actuarially fair annuity markets will choose. They show that an individual without annuities who lives to age 85 will rationally choose to consume only 73 percent as much at age 85 as was consumed at age 65 . At age 95, this individual will be consuming less than half as much each year as at age 65 . If he or she had annuitized personal wealth at age 65 , consumption would be the same at all of these dates. This general pattern is reduced but not reversed by the inclusion of realistic institutional features such as an assured minimal income in old age from Social Security.

One important distinction among annuity products concerns the nature of the payout stream, in particular whether the payout is a fixed nominal amount for the duration of the liquidation phase. Historically, most annuities provided fixed nominal payouts. Yet many individuals who purchase annuities are presumably interested in ensuring for themselves a minimum level of purchasing power, or real income, for the remainder of their lives. (Real income is income adjusted for the effects of inflation.) Inflation, which is uncertain when the annuity is purchased, can reduce the real value of the annuity payout. The utility gain for an individual with access to a market for real annuities is greater than that associated with access to a nominal annuity market. Diamond (1977) points to the absence of markets for purchasing power-adjusted annuities as one of the important rationales for governmentprovided retirement income programs. The recent introduction of Treasury securities which guarantee returns after inflation may lead to changes in this situation, and in particular, may facilitate the introduction of purchasing-power-adjusted annuities by some insurance 
companies.

Variable annuities, one class of annuity products, are designed to reduce the risk of inflationary erosion of real benefit payments. They have been one of the most rapidly growing insurance products of the last two decades. Variable annuities offer the opportunity to link payouts to the returns on an underlying asset portfolio. If the underlying assets provide a hedge against inflation, so will the payouts on the variable annuity. Variable annuities, however, do not always provide an inflation hedge. The weak performance of the U.S. stock market during the 1970s, when inflation rates were substantial, provides an example of one period during which variable annuities with payouts linked to the stock market did not provide a hedge against inflation.

\subsection{Statistical Overview of Annuity Markets}

Tables 1 through 3 present an overview of the significance of annuities in the U.S. insurance market. Table 1 presents the value of insurance company payouts on life insurance policies and on annuities over the period 1940-93, converted to 1994 dollars by adjusting for the effects of inflation. Although annuities represented less than 10 percent of the combined payouts on life insurance and annuities in the period before World War II, they grew more rapidly than life insurance in the five decades tracked in the table. By the early 1990s, annuity payouts constituted nearly $\mathbf{4 0}$ percent of combined payouts.

Table 2 reports the premium income received by insurance companies for annuity policies over the 1951-93 period. The table shows both the substantial growth of real annuity premiums, particularly between 1951 and the mid-1960s, and the breakdown of annuity premiums between individual and group policies. Although premiums on group policies were three to five times greater than the premiums on individual policies throughout the 1950 s and 1960s, individual annuities have grown more rapidly in the last two decades. 
In 1993, the latest year for which data are available, premiums for individual and group annuities were almost equal. This reflects both the decline in the growth of defined benefit pension plans and the rapid expansion of individual annuity products, particularly variable annuities. By comparison, life insurance premiums (measured in 1994 dollars) were $\$ 38.7$ billion in 1951, more than seven times greater than annuity premiums. In 1993, life insurance premiums were $\$ 96.9$ billion, or roughly 60 percent of annuity premiums.

Statistics such as those reported in Table 2 may understate the actual significance of annuity contracts. As Murphy (1950) notes, virtually all permanent life insurance contracts other than term life accumulate cash value. This accumulated value can be used to purchase an annuity. Such policies are classified as life insurance policies, but they can also be viewed as partly annuity products. Provisions regarding withdrawals and annuity conversions are almost always specified in the life insurance policy at the time of purchase.

Table 3 presents information on the reserves that insurance companies hold against future payouts on annuities and life insurance policies. The data span the 1967-93 period, and show the rapid growth of annuities over this period. Whereas total annuity reserves were less than half of life insurance reserves in the mid-1960s, they have grown to more than twice the value of life insurance reserves in 1993. In part, this reflects the growth of term life insurance, for which reserve requirements are lower than for other types of life insurance. The data on annuity reserves are divided into individual annuities, which have grown most rapidly over this period; group annuity reserves, which have increased by more than a factor of five since the data began; and reserves for supplemental annuities, which have declined in real terms. Supplemental annuities are typically purchased in association with life insurance policy payouts. 


\section{The Early History of Annuities}

Not surprisingly, since uncertainty about length of life is a ubiquitous source of risk, financial contracts similar to annuities have a long history. James (1947) reports that ancient Roman contracts known as annua promised an individual a stream of payments for a fixed term, or possibly for life, in return for an up-front payment. Such contracts were apparently offered by speculators who dealt in marine and other lines of insurance. A Roman, Domitius Ulpianus, compiled the first recorded life table for the purpose of computing the estate value of annuities that a decedent might have purchased on the lives of his survivors.

Single-premium life annuities were available in the Middle Ages, and detailed records exist of special annuity pools known as tontines that operated in France during the 17th century. In return for an initial lump-sum payment, purchasers of tontines received life annuities. The amount of the annuity was increased each year for the survivors, as they claimed the payouts that would otherwise have gone to those who died. When the second-tolast participant in a tontine pool died, the sole survivor received the entire remaining principal. The tontine thus combined insurance with an element of lottery-style gambling.

During the 1700s, governments in several nations, including England and Holland, sold annuities in lieu of government bonds. The government received capital in return for a promise of lifetime payouts to the annuitants. Murphy (1939) provides a detailed account of the sale of public annuities in England in the 18th and early 19th centuries. Annuities initially were sold to all individuals at a fixed price, regardless of their age or sex. As it became clear over time that mortality rates for annuitants were lower than those for the population at large, a more refined pricing structure was introduced.

In the United States, annuities have been available for over two centuries. In 1759, Pennsylvania chartered the Corporation for the Relief of Poor and Distressed Presbyterian 
Ministers and Distressed Widows and Children of Ministers. It provided survivorship annuities for the families of ministers (see James 1947). In Philadelphia in 1812, the Pennsylvania Company for Insurance on Lives and Granting Annuities was founded. It offered life insurance and annuities to the general public and was the forerunner of modern stock insurance companies.

During the 19th century, the market for annuities grew slowly while that for life insurance grew quickly. This disparity in part reflects the different risks that these insurance products address. Individuals who, if they died unexpectedly, would leave dependents in need of income support provide the traditional market for life insurance. Individuals who have no dependents or relatives to provide support if they outlive their resources provide the natural market for annuities. Extended families, common in the 19th century, provided an informal alternative to structured annuity contracts. The falling incidence of multigeneration households in the early 20th century contributed to the growing demand for annuity products. The role of families and other informal arrangements in insuring longevity is noted by Murphy (1950).

\section{Individual Annuities}

The market for individual annuities has expanded substantially in the last century. To understand its growth, one must recognize the range of different annuity products available to individuals and the risks the products are designed to insure against. Individual annuity products differ in their provisions for asset accumulation and in the terms under which the accumulated principal is dispersed during the liquidation phase. This section describes the primary types of individual fixed annuities and summarizes the growth of the individual annuity market in the United States. 


\subsection{Typology of Individual Annuities}

Annuities can be categorized along many dimensions, including the number and timing of premiums, the number of lives covered, the nature of the payouts, and the date at which benefits begin. The following outlines these different types of annuities.

Method of paying premiums:

Single premium

Fixed annual premium

Flexible premium

Number of lives covered:

One

More than one (joint life, joint and survivor annuities)

Waiting period for benefits to begin:

None (immediate annuity)

Some waiting period (deferred annuity)

Nature of payouts:

Life annuity without refund

Guaranteed minimum annuity (period certain annuity, refund annuity)

Periodic withdrawals (flexible payout alternatives)

The simplest individual annuity contract is a single-premium immediate annuity. In return for a single premium payment, the annuitant receives a guaranteed stream of future payments that begin immediately. These payments can end when the annuitant dies (a simple life annuity), when both the annuitant and a coannuitant, such as a spouse, have died (a joint life survivorship annuity), or at the later of a fixed number of years or the date of death of the annuitant (life annuity with stipulated payments certain). These types of annuities address different insurance needs. A simple life annuity is primarily designed to insure annuitants against outliving their resources; a joint life survivorship annuity addresses this risk and also provides retirement income for dependents. 
The "payout certain" annuity is often attractive because potential annuitants are unwilling to turn over a capital sum to an annuity provider and risk dying shortly thereafter without receiving many annuity payments. The "fixed payments certain" product overcomes this inhibition by ensuring that payments will be made to the annuitants' beneficiaries for at least a fixed period. The level of the annuity payout associated with a "fixed payments certain" contract is correspondingly lower than that for a simple life annuity.

Black and Skipper (1994) contrast the pricing of different types of single-premium annuities. They report that a 65 -year-old man could expect roughly $\$ 7.22$ per month in annuity payout per $\$ 1,000$ premium payment for a fixed life annuity, compared with $\$ 6.64$ per month for a 10-year certain and continuous annuity la life annuity with a guarantee of a minimum of 10 years of payments) and $\$ 6.19$ for a cash refund annuity, which refunds the unpaid nominal amount of the premium in the event that the annuitant dies before the full amount of the initial premium has been distributed. The differences in purchase rates are a function of time and interest rates.

In addition to the immediate annuities described above, a second broad class of individual annuities is deferred annuities. A single-premium deferred annuity, for example, includes a waiting period between the premium payment and the beginning of annuity payouts. The promised stream of payments for a given premium is greater for a singlepremium deferred annuity than for a single-premium immediate annuity, since the premium is invested and earns returns between the date when it is paid and the date when the payouts begin.

A variant on such an annuity, one that provides for multiple premium payments, could represent a saving plan for an individual who plans to use an annuity to draw down accumulated resources. This is known as an annual-payment annuity. It specifies a stream 
of premiums that the policyholder will pay during the policy's accumulation phase. At the conclusion of this phase or possibly some years afterward, the policy enters its liquidation phase and the annuitant and beneficiaries begin to receive payouts from the accumulated principal. Annual-payment annuities can be useful planning tools for those who are trying to accumulate the resources to receive a substantial annuity during retirement. Single-premium deferred annuities have been the dominant contract in the individual annuity market of the last fow decades.

One of the most popular annuity products is the flexible-premium deferred annuity, which permits annuitants to make cash contributions at times of their choosing and allows the accumulated value of these premium contributions to be converted to an annuity at some future date or specified age of the annuitant.

\subsection{The Growth of the Individual Annuity Market}

The annuity business was a small share of the insurance market until the Great Depression. Data compiled by the Temporary National Economic Commission (TNEC) (1941, 112) suggest that, over the period 1866-1920, annuity premiums averaged only 1.5 percent of life insurance premiums received by U.S. insurance companies. The Great Depression, and the associated financial panic and bank failures, led many investors to seek reliable investment vehicles for their savings. Individual annuities, many offered by insurance companies with long and stable financial histories, were such vehicles, and they grew rapidly during the 1930s. TNEC (1941) data show that sixty-eight percent of all annuity premiums received between 1913 and 1937 were received between 1933 and 1937. In 1934-36, the premium income on newly issued individual annuities exceeded that on newly issued ordinary life insurance for the 26 large companies studied by the TNEC.

As a share of payouts, reserves, or total premium income, annuities were still a small 
part of the insurance business in the 1930s. They accounted for 1.79 percent of all insurance company disbursements over the 1929-38 period, compared with 24.3 percent for death claims and 23 percent for policy surrender values (TNEC 1941, 324). Annuities, at 8.56 percent, accounted for a greater share of premium income during this period, and individual annuities accounted for 80 percent of annuity premiums. In 1938, annuity reserves were $\$ 2.67$ billion, compared with $\$ 16.83$ billion in life insurance reserves.

Although the individual annuity market grew rapidly in the 1930s, it represented only a small fraction of the insurance industry at the end of this period. Many firms that had sold policies during that decade subsequently experienced losses on their annuity contracts, for two reasons. First, the rate of return earned on insurance reserves fell during the early 1930 s. Long-term interest rates on Moody's AAA corporate bonds averaged 4.68 percent between 1928 and 1932 but 3.45 percent between 1933 and 1940. The real interest rate was much greater than the nominal rate in the early 1930 s. The consumer price index fell 20.3 percent between 1928 and 1932, raising the real return to lenders. Long-term interest rates fell below 3 percent in the late 1930s. Because annuities had been sold assuming that prevailing interest rates from earlier periods would remain in force, the drop in rates led to investment earnings below what was needed to service these contracts. Campbell (1969) reports that the net earnings rates of life insurance companies reached a high of 5.05 percent in 1930 but declined for nearly two decades afterward, falling to 2.88 percent in 1947 . This was reflected in the poor profitability of annuity contracts.

A second factor in annuity losses was the longevity of annuitants relative to the assumptions that insurance companies used in pricing their annuity contracts. Life expectancy did not improve substantially during the Depression. Life expectancy for white men at age 60 was only 0.2 years longer in 1940 than in 1930 . For women, the gain in life 
expectancy was slightly larger: 0.5 years (Historical Statistics, Series B1 24-125, vol. 1). But as Gilbert (1948) and the TNEC $(1941,331)$ explain, the mortality tables that life insurance companies used to price annuities were revised several times during the 1930s to reflect the lower mortality risk for annuitants than for the general public. The mortality experience of female annuitants was particularly overstated by the life tables in use at the beginning of the 1930s.

Gilbert (1948) compares the 1868 American Experience Table of Mortality, long a standard reference in the insurance industry, and the "expectation" table adopted in 1938 for annuity purposes. The tables show large gains in life expectancy at extreme ages, especially for women. The 1868 table combined both men and women to yield a life expectancy of 8.48 years at age 70 . In contrast, the 1938 table shows a life expectancy of 15.62 years for female annuitants at age 70 . The overly optimistic mortality assumptions built into annuities sold at the beginning of the 1930 s contributed to the losses on these products later in the decade.

The annuity contracts that grew in popularity during the 1930 s emphasized the role of annuities as retirement savings and investment vehicles. Annual-premium retirement annuities-contracts that allowed individuals to make premium contributions each year, to accumulate a capital fund, and then to choose from a number of payout options at the date of their retirement or another advanced age-expanded particularly rapidly. Retirement annuities were attractive retirement saving vehicles for several reasons. They offered returns that were often greater than those available elsewhere for small investors. They provided an option to purchase an immediate single-premium annuity at a future date, typically at terms specified at the beginning of the accumulation period, if the participant decided that was the best way to decumulate assets. Perhaps most important, annuities were supplied by secure 
financial institutions. Gilbert (1948) notes that even though surrender charges could sharply reduce the return on these products for those who redeemed them before maturity, this did not prevent the rapid expansion of the deferred annuity market in the 1930s.

Annuity premiums, the amount an annuitant had to pay to purchase a given payout stream, increased during the 1930s. Gilbert (1948) reports that in 1930 Aetna Life Insurance Company would sell a $\$ 100$ immediate annual annuity to a 65 -year-old man/woman for a premium of $\$ 925 / \$ 1,040$. By 1940 , the premiums had increased to $\$ 1,220 / \$ 1,435$.

The individual annuity market expanded throughout the postwar period. As the data in Table 2 show, individual annuity premium payments increased almost every year. However, comparing these premium payments with a yardstick for the size of the economy, such as gross domestic product, can be more revealing. Individual annuity premiums were 0.064 percent (six one-hundredths of 1 percent) of GDP in 1951. They declined to 0.053 percent in 1961 , then began to increase: to 0.110 by $1971,0.339$ percent in $1981,0.903$ percent in 1991, and finally to 1.21 percent in 1993 . The early 1960 s thus marked the beginning of the growth phase for individual annuities, with much of the growth concentrated in the period since the late 1970s.

\subsection{Characteristics of Annuity Buyers}

Survey data on the owners of nonqualified annuity products, such as the information collected and reported in Gallup (1996), provide some insight on the individuals who purchase these policies. In 1993, the average age of individual annuity holders was 63 , and half of these policyholders were retired. Less than one-quarter were under the age of 54, so annuities are primarily a product that attracts buyers who are at or near retirement age. More than three-quarters of the annuity policyholders had annual incomes of less than $\$ 75,000$ per year. The majority of those with annuities reported that they planned to use their annuities 
for retirement income.

The characteristics of annuity products that attract current buyers vary. Roughly threequarters cite tax benefits associated with annuities as a primary reason for purchasing their policy. Another 65 percent cite the safety and reliable income associated with an annuity, and more than half indicate that the long-term saving plan associated with an annuity product was an important attraction. A substantial fraction, nearly half, of all annuity holders report that they used a one-time income receipt, such as an inheritance, to purchase their annuity.

\section{Group Annuity Plans}

The group annuity market, which is linked to corporate defined benefit pension plans, was pioneered by the Metropolitan Life Insurance Company in the early 1920s (see James 1947). Life insurance companies began underwriting group life, health, and disability policies for large corporations in the years after World War I. Providing life annuities to retirees was a natural extension of this business.

Most early corporate pensions were financed on a pay-as-you-go basis, with the firm making payments to beneficiaries from current earnings. In 1921, Metropolitan began to write small contracts to manage corporate pension programs, collecting contributions while workers were employed and, in return, paying out benefits when they were retired. Metropolitan introduced its own retirement pension program in 1925 and began actively marketing "group annuities," the name for structured pension programs, in 1927. In the first year of operation, Metropolitan sold only 30 contracts for group annuities, covering fewer than 40,000 individuals.

The group annuity market suffered from the same difficulties as the individual annuity market in the early 1930s, with low investment returns leading to losses on group annuity 
contracts. This experience, coupled with the passage of the Social Security Act of 1935 (which promised workers a minimal retirement benefit) led to slow growth of group annuities. By 1941, James (1947) reports, only 269,101 individuals were covered by group annuity policies with Metropolitan Life Insurance Company.

The typical policy at this time (described, for example, by Dublin 1943), required employer and employee contributions during the employee's active service. The employee was eligible to receive an annuity beginning at age 65 , with some provisions for retirement at other ages. At retirement, the employee could typically choose between a lump-sum payout of his total contributions, and the "paid-up option" in which these contributions were used to purchase a life or joint life annuity. Employer contributions were usually applied to purchase an annuity. The goal of most group annuity plans was to provide, in conjunction with individual benefits from Social Security, a retirement income that replaced roughly $40-60$ percent of the retiree's earnings from employment (see Dublin 1943, 185).

The group annuity business grew rapidly in the late 1940 s and throughout the 1950 s. Table 4 charts the growth of group annuities since the mid-1950s. In 1958, 3.9 million workers were covered in various types of group annuity plans. This number grew to 38 million by 1988 and to nearly 45 million by 1993 , the last year for which data are available. At one time essentially all group annuities were associated with defined benefit pension plans, though not all defined benefit plans were administered through group annuities. In more recent years, group annuities have also been used in conjunction with defined contribution plans. Hoffman and Mondejar (1992) provide data on the assets of insured and noninsured private pension funds. In 1950 , insured pension fund assets were $\mathbf{4 0}$ percent of the total assets of private pension funds; this fraction declined gradually to 31 percent by the end of the 1980s. The broad trends in this ratio are sensitive to the mix of defined benefit and 
defined contribution pension plans.

\subsection{Troology of Group Annuity Products}

Group annuity contracts take several forms. The first type to achieve popularity was the deferred aroup annuity contract. An employer purchasing such a contract makes periodic payments to an insurance company, which applies these payments to the purchase of deferred annuities for covered workers. The purchase price of these annuities is specified by the employer's contract with the insurance company, so the insurer indemnifies the employer against changes in rates of return, mortality risk, or other factors that could alter the pricing of deferred annuities. Maclean (1962) reports that such policies are often structured so that the employer receives a dividend from the insurance company if mortality experience or investment returns prove to be more favorable than the initial contract anticipated. The employer does not pay more, however, if supplying deferred annuities turns out to be more expensive than the insurance company had originally anticipated. This type of contract covered 71 percent of the individuals with group annuity contracts in 1950 but declined to only 48 percent a decade later.

A key attraction of deferred group annuity contracts is that employees know they have a certain pension income, which is guaranteed by the insurance company writing the annuity contract. Managers in turn know that they have met their future pension obligations in full. Because some workers will not remain with the firm long enough to collect pension benefits, however, fully-funded deferred group annuity contracts require the employer to set aside funds for future pension liabilities that may not materialize. These contracts also give employers little flexibility in choosing the funding level for their pension.

A second type of group annuity contract, the deposit administration contract, grew in popularity during the 1950 s. This type of contract offers more flexibility in the timing of 
employer contributions and a more direct link between employer cost and the mortality or turnover experience of employees than does the deferred group annuity contract. Contributions to the deposit administration plan are held by the insurer in an unallocated fund. The insurer promises a minimum return on this fund. When an employee retires, the insurer withdraws an amount sufficient to purchase an immediate fixed annuity for the amount of the retiree's assured retirement benefit from the fund account. The insurer does not indemnify the employer against changes in the price of fixed annuities. Although the insurance company bears all risks of mortality and rate-of-return fluctuations for retired employees, the employer bears these risks for employees who have not yet reached retirement.

The employer may be able to contribute less to the reserve fund than the required contributions under a deferred group annuity contract. Deposit administration plans expanded very rapidly in the 1950s, from covering only 10 percent of all individuals in insured pension plans in 1950 to covering 31 percent by 1959. Deposit administration plans and deferred group annuities are aggregated under the single entry "group annuities" in Table 4.

A third class of group annuity contract, first offered in 1950 and one of the most popular in subsequent years, is the immediate participation quarantee (IPG) contract. This is a variant of the deposit administration contract, with a fund account maintained by the insurer but with even more direct links between the mortality experience of covered employees, returns on investment, and the pension costs of the employer. With an IPG plan, if the employer maintains a fund account balance large enough to fund the guaranteed annuities for all retirees, then the employer's account is credited with the actual investment experience of the insurer, and the actual payments to retirees are withdrawn from this account. In this way the employer is essentially self-insuring the mortality experience of retirees and receiving actual rather than projected investment returns. If the employer's fund balance drops below 
the amount needed to fund the required guaranteed annuities, however, then the plan becomes a standard deferred annuity contract, and the insurer uses the account balance to purchase guaranteed individual annuities for all participants in the pension plan. Provided the account balance is high enough, the employer bears the investment and mortality risks associated with the plan. These risks are assumed by the insurer if the account balance falls below the threshold.

The rules governing an employee's participation in defined benefit private pension plans vary from employer to employer, with corresponding effects on participation in associated group annuity programs. Several common features nevertheless deserve comment. First, when firms introduce these plans, they typically purchase deferred annuities for the pension liabilities associated with prior service of current employees. Second, if employees vested in a pension plan die before the plan's retirement age, their contributions will be returned, in most cases with interest; the employer's contributions to the pension plan will not be returned. Third, an employee who leaves the firm before reaching retirement age may choose to withdraw the current value of his or her pension benefit as a lump sum or to receive the benefits due at retirement age. With the advent of individual retirement accounts and other self-directed retirement income accounts in the early 1980s, workers who were leaving the firm were able to roll over their accumulated pension wealth into another retirement saving account.

\subsection{Group Annuities and Pension Policy in the United States}

Group annuity contracts grew rapidly during the 1950 s and 1960 s. They were originally linked to defined benefit pension plans, which promise workers a retirement benefit specified by a formula typically depending on years of service and salary history. Their growth continued as employment at firms with defined benefit pension plans increased and as various 
legislative changes raised the fraction of the workforce at these firms that was covered by a pension. For a variety of reasons, however, the growth of defined benefit plans slowed and then reversed during the 1980 s. Defined contribution plans, which permit employers to make contributions to an investment account maintained on behalf of the worker but which do not promise any particular stream of postretirement benefits, have grown rapidly since the early 1980 s.

Currently, very few new defined benefit plans are being created, whereas the growth of defined contribution plans continues unabated. As was noted above, the use of group annuities has been changing, and these annuities are increasingly used in conjunction with defined contribution plans.

Table 5 shows substantial changes in the relative flows of contributions to defined benefit and defined contribution pension plans during the 1980 s. The table shows the number of defined contribution and defined benefit pension plans, participants in these plans, and contributions to these plans, during the period 1975-91. The number of defined contribution plans more than doubled between 1975 and 1982 and then rose another 50 percent between 1982 and 1989. The number of defined benefit plans increased during the 1975-82 period, but the increase was slower than that for defined contribution plans. Between 1982 and 1991, however, the number of defined benefit plans actually declined, with the 1991 number more than 40 percent below the peak. The number of participants peaked in 1984, and the number of active participants (those who were not retired) peaked in 1981. In contrast, the number of defined contribution plan participants increased throughout the 1980s, although more slowly than the number of plans.

The last column in Table 5 tracks contributions to defined contribution and defined benefit pension plans. The disparity between the contribution series is even more dramatic 
21

than that between the number of participants or the number of plans. In constant 1989 dollars, defined contribution plan contributions increased from $\$ 35.4$ billion in 1980 to $\$ 73.7$ billion in 1991. Contributions to defined benefit plans, however, peaked at $\$ 64.1$ billion in 1980 and 1981 and then declined to only $\$ 27.4$ billion by 1991 . Defined benefit plan contributions were even lower in 1989 and 1990.

The shift from defined benefit to defined contribution pension plans was the result of several coincident developments, including regulatory changes and a shift in employment growth from industries that historically offered such plans (such as manufacturing) to industries that did not (services and trade). The changing regulatory treatment of defined benefit and defined contribution pension plans began with the Employee Retirement and Income Security Act of 1974 (ERISA). ERISA imposed minimum plan standards for participation, vesting, and retirement, as well as requirements for funding past service liability. It also established the Pension Benefit Guaranty Corporation (PBGC) to insure pension benefits to employees in defined benefit plans and financed this insurance program with taxes on existing plans. ERISA placed a lower regulatory burden on defined contribution plans, which were subject only to the same minimum plan standards that affected defined benefit plans. Post-ERISA legislation has raised PBGC premiums, required faster funding of liabilities, and penalized employers for claiming excess assets of terminated defined benefit plans.

\section{Variable Annuities}

Both the individual and group markets have changed over time, from markets primarily for fixed annuities to markets with growing use of variable annuities. Fixed annuities provide a guaranteed nominal payout during their liquidation phase. They distribute a given principal across many periods, but they do not provide a constant real (i.e., adjusted for inflation) 
payout stream if the price level changes. When inflation is low, the real value of the annual distribution will not vary much over the liquidation period. But even modest inflation rates of 3-5 percent per year, if they persist throughout the liquidation period, can lead to substantial erosion in the real value of annuity payouts. At an inflation rate of 3 percent per year, for example, the real value of annuity payouts in the first year of an annuity liquidation period is more than twice that of the same nominal payout 24 years later. At an inflation rate of 6 percent per year, the real value of payouts is halved in only 12 years.

Variable annuities, by design, address the risk of purchasing power erosion that is associated with fixed nominal annuities. Unlike fixed annuities that promise a constant nominal payout, variable annuities provide an opportunity to select a payout that bears a fixed relation to the value of an asset portfolio. If these assets tend to rise in value with the nominal price level, then the payout on the variable annuity will adjust to mitigate, at least in part, the effects of inflation. Because variable annuities are defined in part by the securities that back them, they are more complex contracts than fixed annuities. In spite of their complexity, however, they have become one of the most rapidly growing annuity products in recent years.

\subsection{The Mechanics of Variable Annuities}

Variable annuities are structured to have both an investment component and an insurance element. During the accumulation phase, premium payments are used to purchase "investment units," the price depending on the value of the variable annuity's underlying asset portfolio. For example, if this portfolio consists of common stocks and if share prices are high when a premium payment is made, then this payment will buy relatively few units, and vice versa. During the accumulation phase, variable annuities resemble mutual funds in many respects, although there are differences, and the assets in many recent variable annuity 
products are explicitly managed by mutual fund providers. The dividends, interest, and capital gains on the assets that underlie the investment units are reinvested to purchase additional investment units.

When the accumulation phase of the variable annuity ends, the accumulated value of the investment units is transformed into "annuity units." This transformation occurs as if the accumulation units were cashed out and used to purchase a hypothetical fixed annuity. The annuitant does not receive a stream of fixed annuity payments, but this hypothetical annuity plays an important role in computing actual payouts. The payout amount for the hypothetical annuity is used to credit the annuitant with a number of annuity units. Many variable annuities also allow annuitants the option of choosing a fixed annuity stream, or some combination of a fixed stream and a variable stream of payouts.

The actual variable annuity payout in each period depends on the number of annuity units that the annuitant is credited with, and, over some range of asset returns, on the value of the assets in the variable annuity's underlying portfolio. If the value of this portfolio rises by more than the increase implicit in the assumed interest rate, after the annuitant has converted to annuity units, for example because of rising nominal prices, then the payout will rise during the payout phase. If the value of the underlying assets falls, however, the value of the payout will also decline. The variable annuity's possibility of fluctuating payments is both an attraction (it provides potential protection against rising consumer prices) and, for some potential buyers, a disadvantage (the nominal payout stream is not certain).

Several product innovations during the last two decades have expanded the menu of investment options available for variable annuities. First, the range of portfolio investments that can be held through variable annuity policies has increased. Although the first variable annuities focused exclusively on diversified common stock portfolios, policies now offer 
variable annuities tied to more specialized portfolios of equities as well as to bonds or other securities. Variable annuities typically allow policyholders to move their assets among various policy sub-accounts, usually with different investment objectives, without fees or penalties. Second, virtually all variable annuities now offer lump-sum withdrawal options after the policy has reached a specified maturity date, as well as the possibility of withdrawing the principal in a set of periodic lump-sum payments. These features make it possible to use variable annuities as an asset accumulation vehicle without necessarily purchasing an annuity-like payout stream when the accumulation phase is over. This is because variable annuity contracts contain a purchase rate guarantee. Finally, some no-load mutual fund families have begun offering variable annuities in conjunction with some insurance companies in recent years. Schultz (1995) reports that investment management expenses for funds associated with variable annuities that invest primarily in diversified U.S. equity portfolios average 0.76 percent per year, which combines with the 1.23 percent average annual insurance expenses on these variable annuity products for a total expense ratio of 1.99 percent. Variable annuities and other investment alternatives are compared in more detail below.

\subsection{The Growth of Variable Annuities}

Variable annuities were introduced in the United States by the Teachers Insurance and Annuities Association-College Retirement Equity Fund (TIAA-CREF) in 1952. The first variable annuities were qualified annuities that were used to fund pension arrangements. Variable annuities grew slowly during the next three decades-in part, as Green (1977) explains, because of the need to obtain regulatory approval for these products from many state insurance departments. Because variable annuities are usually backed by assets, such as corporate stocks, that do not guarantee a fixed minimal payout, the reserves that back these policies are maintained in separate accounts from the other policy reserves of life insurance 
companies. Maclean (1962) notes that no major insurance company other than TIAA-CREF had issued a variable annuity policy as of 1960 , primarily because state laws prohibited insurers from supplying a new class of products backed by common stock assets that were segregated from the insurer's other assets. Campbell (1969) provides a detailed account of the introduction and growth of variable annuity products, with particular attention to the regulatory hurdles that had to be cleared to market these products.

The slow growth experienced in 1950 s and 1960s has been reversed in recent years. The growth rate of variable annuity premiums during the last decade has been second only to health insurance premiums among insurance products. Between 1989 and 1993, individual annuity premiums (measured in 1994 dollars) increased from $\$ 58.6$ to $\$ 71.8$ billion, largely as a result of growth in variable annuity sales.

Table 6 chronicles the growth of the variable annuity market. It shows the increase in the number of variable annuity policies in force, as well as the growth in variable annuity premium payments. The number of variable annuity products in force and the premiums received on these policies have grown rapidly, but since many of these policies are not yet mature, payouts have not increased commensurately. One open question is whether a substantial fraction of the assets currently accumulating in variable annuity contracts will ultimately be used to purchase life annuity contracts, or whether it will be withdrawn as lump sums or in other forms.

Table 6 shows only 670,000 contract owners in variable annuity policies in 1977. compared with 3.7 million in individual fixed annuity policies that year. By 1993, the number of variable contract owners had increased to 5.25 million, and the number of fixed contract owners had grown to $\mathbf{2 1 . 5}$ million. Both variable and fixed annuities grew rapidly between the late 1970s and late 1980s. In more recent years, variable annuities have grown faster 
than fixed annuities as Table 6 illustrates. Variable annuity premiums increased fivefold between 1991 and 1994, compared with only a 15 percent increase in premiums for individual fixed annuities.

Table 7 further documents the growth in variable annuities and shows that both individual and group variable annuity policies have expanded in recent years. It shows the growth in capital reserves that life insurance companies hold against variable annuity products. The early growth of variable annuity policies was concentrated in group policies. As recently as the late 1960 s, more than 95 percent of the reserves for variable annuity policies were held in group policies. Individual variable annuity policies, however, have grown more quickly than group policies during the last two decades. The policy reserves for individual variable annuity policies surpassed those for group policies in 1987; by 1993 , individual variable annuity reserves were more than twice those for group policies.

\subsection{Prospects for Variable Annuities}

Several factors have contributed to the recent growth of the individual annuity market in general and to the variable annuity market in particular. These factors will likely continue to generate strong demand. First, the opportunity annuities provide for tax-deferred savings is not unique, but it is becoming rarer. The Tax Reform Act of 1986 limited the opportunity for tax-deferred saving through individual retirement accounts. For married couples with adjusted gross income of more than $\$ 40,000$ and individuals with adjusted gross income of $\$ 25,000$ in 1994, IRA contributions were not fully deductible. For couples with incomes above $\$ 50,000$ or for individuals with incomes above $\$ 35,000$, no deduction was allowed for an IRA contribution. The Tax Reform Act of 1986 also reduced the amount of tax liability that could be deferred through qualified pension plans, by lowering marginal tax rates, and it limited to $\$ 150,000$ the amount of income on which taxpayers could base contributions to 
qualified plans. Subsequent legislation has continued the pattern of making qualified retirement plans less attractive means for saving and has even introduced a 15 percent surtax that applies to withdrawals in excess of $\$ 150,000$ per year from qualified retirement plans. As these plans have become less attractive, annuities have become relatively more attractive.

Second, demographic trends and the nature of the current budget policy environment suggest continued interest in annuity products. As the baby boom generation reaches late middle age, when households traditionally begin planning for retirement, products designed to provide retirement income are likely to draw attention. There is some anecdotal evidence (see, e.g., Covaleski 1994), that baby boomers have been an active market particularly for variable annuity products. The current uncertainty surrounding the future of Social Security, and the question of whether Social Security will provide as generously for the retirement of aging baby boomers as for that of their parents, is likely to generate additional demand for retirement-oriented saving products.

The growth of variable annuities in recent years is probably related in part to the increase in stock prices, and the coincident decline in long-term interest rates, that has stimulated investor interest in annuities that offer returns linked to equities rather than fixed income instruments.

\section{Annuities in a Competitive Environment}

Insurers offer a range of different annuity products; these compete in turn with a range of other financial products offered by other financial institutions. As the foregoing discussion emphasizes, different types of annuities are designed to achieve different objectives, and there are trade-offs in the comparison of annuity products with other investment and insurance vehicles. The central trade-offs that investors must evaluate are the benefits of the insurance 


\section{8}

that annuities offer, the costs of potential annuity surrender charges, the potential tax advantages to investing through annuities, the different transaction costs and investment options associated with various financial products.

\subsection{The Insurance Component}

The insurance feature of annuities distinguishes them from many other financial products. All annuities offer insurance against outliving the value of one's resources; some also offer insurance with respect to the rate of return on invested capital. Both fixed and variable annuities insure mortality risk; they are the only products that permit buyers to contract for a guaranteed income for the remainder of their lives. However, while the duration of the income stream is guaranteed for both fixed and variable annuities, the amount of periodic payments is only guaranteed for a fixed annuity.

Many annuities also offer other types of insurance. Some contracts promise that the estate of a purchaser who dies before the accumulation phase has ended will receive the full value of the purchaser's contributions to the annuity. These contracts provide insurance against poor returns on the investments that back the annuity (see Gentry 1994). The nature of such insurance is often quite complex. In January 1994, for example, AlG Life Insurance was marketing a variable annuity policy that provided a death benefit equal to the maximum of the accumulated premiums less withdrawals, the contract value, or the greatest contract value at any sixth anniversary of the policy, plus subsequent deposits net of withdrawals. Valuing such insurance is difficult and requires information on both mortality risk and the random character of investment returns for the assets backing the variable annuity. Gentry and Milano (1994) present illustrative calculations of the value of this insurance to individuals of different ages and under different assumptions about the nature of portfolio risk.

Individual annuities typically also provide insurance with respect to changes in the 
insurance market. Deferred annuities must guarantee the participant the right to purchase an annuity on particular terms some years in the future. This insures against changes in aggregate mortality risk that result in changes in the pricing of annuities, as well as against changes in expected rates of return that result in modified terms in newly issued annuity contracts.

The cost of providing insurance affects the pricing of annuities, and insurance value must be considered in evaluating potential annuity investments. The management expenses associated with variable annuities typically average between 100 and 150 basis points per year, substantially higher than the comparable expenses for many mutual funds. Variable annuities are therefore most attractive to individuals who value the insurance associated with them and who are prepared to pay for this insurance, or who value the tax-deferred "inside build-up" associated with these accounts.

\subsection{Surrender Charges}

Annuities, unlike some other financial products, feature a surrender charge. These charges, found in many but not all deferred annuity contracts as part of the initial contractual agreement between the buyer and the annuity provider, stipulate that an annuitant who decides to cancel the policy before its maturity date, e.g., five or ten years, must pay a fee to the insurer. Insurers justify these provisions as needed to recover the commission and other production costs associated with annuity products. When assets are held in an annuity product for a long period until the maturity date, the insurer can cover these costs through the annual management fees and expenses of the annuity. When the annuity contract is terminated prematurely, however, the total collected from such management fees is reduced, and the insurer collects a surrender charge to compensate for these lost fees.

The combination of surrender charges and income tax penalties for premature 
withdrawal of annuity assets makes long-term investors who do not expect to need their invested assets in the short term the natural market for deferred annuities. Black and Skipper (1994) report a standard surrender charge of 5-10 percent of the accumulated value, typically with a declining schedule and ceasing after a fixed period of years. These charges can substantially reduce the rate of return on annuity assets for those who terminate their contract prematurely. In addition, the federal income tax levies a 10 percent penalty tax on premature withdrawals from both qualified and nonqualified annuities by individuals under the age of $59 \frac{1}{2}$. This tax applies only to the income that has been accumulated in the annuity contract. These withdrawal penalties, which are very similar to those on early withdrawals from qualified retirement plans, further encourage annuity investors to accumulate for the long term and reduce the return earned by those who withdraw their assets.

Surrender charges were more prevalent in the 1930 s and 1940 s than at present. In fact, some annuity products marketed in recent years do not include surrender charges. Pallay (1995) estimates that approximately one-fourth of annuity reserves are currently accounted for by annuities with no surrender charges, although some of this includes contracts on which surrender charges have expired. An somewhat dated illustration of the potential effect of surrender charges on the returns earned by those who terminate their annuity contract before maturity is provided by Gilbert (1948), who focuses on the types of annuities that were common in the early postwar years. He focuses on a typical deposit annuity in the 1940s, which imposed a loading charge as well as an early surrender charge. If the annuitant could directly earn the 3 percent rate of return assumed in the annuity, then the capital fund an investor could build by contributing premium contributions to a personal account would grow faster than the surrender value of the annuity. In each of the first 11 years of a typical annuity policy, Gilbert (1948) showed, the surrender value was less than the sum of the 
nominal premiums that the annuitant had paid. Whether an individual can match the return promised in annuity contract depends on existing investment opportunities and the degree to which the insurance firm offering the annuity provides valuable investment direction.

Annuities are not the only products with surrender fees. Some mutual funds impose a special charge on investors who withdraw their assets before a specified holding period. The nature of surrender charges and their effect on the investment return for these products are important factors to consider in comparing annuities with other financial products.

\subsection{Tax Treatment of Accumulation}

The tax treatment of annuities is an attractive feature that has undoubtedly contributed the most to their recent growth. The income on assets held in a deferred annuity account is not taxed until the payout phase, which can be many years after the income accrues. Annuities therefore afford an opportunity for asset accumulation at the pre-tax rate of return.

People planning for retirement may purchase annuities with pre-tax or after-tax dollars. As with qualified pension plans, annuities that are "qualified" (part of a qualified retirement plan) may be purchased with pre-tax dollars; "nonqualified" annuities are purchased with aftertax dollars.

Between the time the annuity is purchased and the time the contract owner receives payouts, no taxes are due on the dividends, capital gains, or interest earned by the assets in the annuity portfolio. When payouts are received, taxes are due on the difference between the annuity payouts and the annuitant's policy basis. The key tax principle is the derivation of an exclusion ratio, an estimate of the ratio of the annuitant's investment in the contract to the total expected payouts on the contract. The exclusion ratio is multiplied by the annuity payout in each period to determine the part of the payout that can be excluded from taxable income. 
Contrasting the tax treatment of annuities and mutual fund investments is helpful. Mutual fund investors pay taxes when their fund receives dividends or realizes capital gains. They are liable for both dividend and capital gains taxes even in periods when they do not sell their shares in the fund; when they do sell their mutual fund shares, they may also be liable for capital gains taxes or eligible for credit for capital losses. Annuity contract owners, in contrast, do not pay any taxes during the accumulation phase of their annuity, although they are liable for a 10 percent early withdrawal penalty and subject to income tax (see above). The annuity provider receives dividends and capital gains, but the annuitant only faces tax liability when payouts from the annuity policy are received. The liquidity of annuities is limited by the fact that the loan, pledge, or assignment of an annuity is treated as a taxable event.

All annuity payouts are taxed as ordinary income, whereas part of the return to mutual fund investments may be taxed at capital gains tax rates, which are lower than ordinary income tax rates for many taxpayers. At death, mutual fund investments are eligible for a step-up in basis and need not be liquidated, but, at death, annuities must be liquidated and the proceeds must be distributed and subjected to tax.

The opportunity to defer taxes on the investment income from assets held in annuities is a powerful tool for building asset balances. Consider, for example, a 35-year-old considering various saving options to fund retirement income, with retirement beginning at age 65. Assume further that this individual plans to invest in an asset with an expected return of 7 percent per year and that investment income faces a marginal tax rate of 28 percent.

Under these assumptions, an investment of $\$ 10,000$ at age 35 will cumulate to $\$ 45,356(=\$ 10,000 * \exp (.07 * 30))$ at age 65 , assuming that each year's asset income is fully taxed and that the after-tax income is reinvested. If the same $\$ 10,000$ were invested in a way that permits tax deferral on asset income, for example in an annuity product, and if 
the pre-tax rate of return on this investment equaled that on the taxable investment, then the principal would cumulate to $\$ 81,662$ at age 65 . Assuming that the withdrawals from this account would be taxed at the 28 percent marginal tax rate and making the conservative assumption that the account value were withdrawn in a lump sum rather than paid out over the annuitant's life, which would permit further asset appreciation, the after-tax value of this account would be

$$
\$ 61,596=10,000+(1-0.28) \bullet(81,662-10,000),
$$

where 10,000 denotes the principal invested. This amount is 35.8 percent greater than the amount in the after-tax investment. If the annuitant faces a marginal tax rate that is lower after retirement than while working, the implied rate-of-return advantage on the tax-deferred annuity vehicle will be even greater.

Table 8 presents additional comparisons between the return to investments that offer tax deferral and investments that do not. It considers individuals with four different return horizons $(10,20,30$, and 40 years) and assumes four different rates of return $(3,5,7$, and 9 percent per year). The table reports the percentage increase in the value of an investment for an individual in the 28 percent marginal tax bracket, the 39.6 percent tax bracket, and a 20 percent marginal tax rate on investment income. The latter category might be representative of an investor who received investment income primarily in the form of capital gains during a period when capital gains tax rates were substantially lower than ordinary income tax rates.

The entries in Table 8 correspond to the $\mathbf{3 5 . 8}$ percent figure reported above. They are the additional value, in percentage terms, that an investor who invested in a tax-deferred rather than taxable format would have at the end of the investment horizon. The disparities are largest when the investment horizon is long, when the rate of return is high, and when the 
marginal tax rate is high. In some cases, particularly those with long investment horizons and high assumed tax rates and rates of return, the principal at retirement from investing in a taxdeferred account can be more than double that of investing through a taxable account.

\subsection{Expenses and Loads}

In a comparison of annuities with other investment vehicles, it is important to consider the investment management fees associated with each product. For annuities, these fees take the form of an expense charge that the insurer deducts each year. For a variable annuity,

this includes a contract expense fee, as well as a fund expense fee. Other investments managed by fiduciaries also have expense charges. Mutual funds, for example, charge investors for management expenses, and they may also charge up-front loads or redemption fees.

Measuring the effective load on annuity products is complex and somewhat controversial, as the debate between Greene (1973) and Gifford (1974) with respect to variable annuities suggests. Annuity loads can arise in part from "adverse selection," the possibility that the mortality experience of annuitants is more favorable than that for the population at large. As noted above in the discussion of annuity pricing during the Depression, annuitants live longer on average than do randomly chosen individuals from the population at large. This implies that calculations that use the average population mortality experience to compute the expected present discounted value of annuity payouts will make annuities appear less financially attractive than they are for actual annuity purchasers. Friedman and Warshawsky (1988) present detailed estimates of the effective loads on immediate fixed annuities in the early 1980s, and Warshawsky (1988) reports historical information on these loads. Mitchell, Poterba, and Warshawsky (1997) present comparable information for the mid-1990s. These studies illustrate the disparity in the effective loads that 
are calculated using population and annuitant mortality tables. Friedman and Warshawsky (1988) conclude that the effective load on individual annuities in the mid-1980s was comparable to that on many other types of insurance. These studies all apply to the market for individually purchased annuities; group annuities may be subject to different effective loads.

\subsection{Regulatory and Legal Environment}

The legal and regulatory environment for annuity products is complex and constantly evolving. The substantial regulation of insurance products in general is partly a result of the long-term nature of the commitments associated with many types of insurance. This is particularly evident in annuities, where purchasers make large up-front payments in return for promises of long-term benefit streams. Fixed annuities are regulated as insurance products, but variable annuities are regulated both as insurance products and as securities. Variable annuities are subject to federal security regulation as well as to state insurance regulation. An active current policy debate is centered on the question of whether insurance companies should be the only financial institutions that can sell annuities or whether other institutions such as banks can enter this market, and how they would be regulated it they did.

The history of annuity regulation is intertwined with that of life insurance regulation. Until 1850, there was little regulation of the insurance industry in the United States. Several insurance scandals led to pressure for regulation, and in 1850, New Hampshire became the first state to appoint a commissioner of insurance. Many other states followed suit in the next two decades, and by the early 1870 s the insurance industry in virtually all states operated under regulatory control, as described by Trieschmann and Gustavson (1995). The primacy of state regulation of insurance markets was confirmed when the U.S. Congress passed the McCarran-Ferguson Act in 1945. State insurance regulations are not uniform, and 
this can affect the scope of annuity products available to consumers in different places. Greene (1977) attributes the slow early growth of variable annuities, after their introduction by TIAA in 1952, in part to the requirement that such products receive regulatory approval in each state.

Insurance regulation arose historically in part because of the complexity of insurance products and the relative lack of sophistication on the part of many insurance buyers. Most annuities, like whole life insurance, involve investment decisions as well as decisions about mortality risk. Insurance regulation involves restrictions on the types of policies that can be offered, constraints on how policies can be explained to potential buyers, limits on what constitutes an acceptable expense, and regulations on the capital that insurance companies must have and on the types of investments that they can purchase with assets that are held against future policyholder claims. Insurance regulations are designed to increase the safety and security of income streams purchased by policyholders.

Black and Skipper (1994) discuss the investment regulations that affect insurance companies, in particular the presence of "legal lists," which describe the set of securities that insurers may invest in and the fraction of their assets that may be held in different securities. These regulations have implications for the rates of return that insurance companies can offer on fixed annuity products, since they typically restrict the amount of high-risk land potentially high-return) securities in insurance portfolios. The foregoing regulations apply to fixed annuities. Group fixed annuities are subject to additional regulations from the provisions of ERISA, largely concerning the structure of contract terms for these products.

Variable annuities are regulated differently than fixed annuities, with insurers maintaining separate asset pools as reserves against variable annuities. This prevents poor returns on the variable annuity portfolio from affecting the capital base for other insurance 
company products. Variable annuities, because of their investment component, are also regulated in part under the federal securities law. These products are subject to provisions of the Securities Act of 1933, the Securities Exchange Act of 1934, and the Investment Company Act of 1940. The first two acts are largely concerned with the prevention of fraud in the issuance and trading of securities, and the ICA of 1940 empowers the Securities and Exchange Commission to regulate the insurance industry's sales of insurance products with a substantial equity component, such as variable annuities and variable life insurance.

Because annuities are both an insurance product and an investment product, there has been a long-standing debate over the set of financial institutions that should be permitted to supply financial products that qualify for annuity tax treatment. The historic rationale for insurance companies underwriting and selling annuities was that they involved precisely the features, such as risk sharing and indemnification, that are the traditional role of insurance firms. The current debate concerns the evolving nature of annuity products and centers on whether the insurance component of many of the currently popular annuity products is large enough to warrant restricting their provision to insurance firms.

Two issues are currently under active policy debate. The first, the subject of the recent NationsBank v. Variable Annuity Life Insurance Company (VAL/C) case, concerns the right of nationl banks to sell annuities as agents of insurance companies. The Supreme Court's decision in this case upheld the authority of banks to sell both fixed and variable annuity products. The second issue concerns annuity underwriting. In late 1994, the U.S. Comptroller of the Currency, who regulates the products that banks may offer, tacitly approved the offering of some annuity-like products by some banks. Proposed banking reform legislation places limits on the authority of the Comptroller to authorize such investment products, and the tax treatment of some annuity-like bank products is also a topic of current policy debate. 
These unsettled issues are subject to frequent new developments.

\section{Conclusion and Future Prospects}

Annuities were a small share of the U.S. insurance market until the 1930s, when two developments contributed to their growth. Flexible-payment deferred annuities, which include a saving component as well as an insurance component, expanded rapidly as concerns about the stability of the financial system drove investors to products offered by long-standing and reputable insurance companies. In addition, the group annuity market for corporate pension plans began to develop in the 1930s; it became the largest part of the U.S. annuity market in the years following World War II. The market for individual annuities expanded in the 1970 s and early 1980s. The most recent development in the annuity marketplace was the expansion of variable annuities in the late 1980 s and early 1990s. These products, which combine the investment features of many mutual funds with certain insurance elements and which qualify for the tax deferral accorded to investment income on life insurance products, have attracted a substantial and growing volume of premiums in recent years.

The demand for annuity products is concentrated at advanced ages. The Gallup (1996) survey data show that more than three-quarters of nonqualified annuity buyers are at least $\mathbf{5 5}$ years old. Growing attention to these products is suggested by the aging of the U.S. population: the proportion of the U.S. population over the age of 65 has grown from 6.8 percent in 1940 to 11.3 percent in 1980 , and is projected at 12.2 percent in 2000 and 16.2 percent in 2020. A central issue for the future is how prospective changes in federal programs that affect the well-being of the elderly, notably Medicare and Social Security, will alter private financial arrangements. Whether potential reductions in these "annuitized" benefit streams will lead to increased private demand for annuity contracts remains an open issue. 
39

A second unresolved policy issue concerns fundamental tax reform and the demand for annuity products. At least part of the demand for these products stems from the opportunity to defer tax on capital income during the accumulation phase of these policies. A shift toward consumption taxation or a general reduction in marginal income tax rates would therefore reduce the demand for these products. 


\section{REFERENCES}

Abel, Andrew, 1986, "Capital Accumulation with Adverse Selection and Uncertain Lifetimes," Econometrica 54: 1079-1098.

Black, Kenneth J., and Harold D. Skipper, Jr., 1994, Life Insurance, 12th Edition IEnglewood Cliffs, NJ: Prentice Hall).

Campbell, Paul A., 1969, The Variable Annuitv: Its Develooment, Its Environment, and Its Future (Hartford: Connecticut General Life Insurance Company).

Covaleski, John M., 1994, "Baby Boom's Explosion in Annuities," Best's Review: Life and Health (November), 45-111.

Dublin, Louis I., 1943, A Family of Thirty Million: The Story of the Metropolitan Life Insurance Company (New York: Metropolitan Life Insurance Company).

Friedman, Benjamin and Mark Warshawsky, 1988, "Annuity Prices and Saving Behavior in the United States," in Zvi Bodie, John Shoven, \& David Wise, eds., Pensions in the U.S. Economy (Chicago: University of Chicago Press), 53-77.

Gallup Organization, 1994, "Survey of Non-Qualified Annuity Owners." Princeton, NJ: Gallup Organization.

Gentry, William M., 1994, "Annuity Markets and Retirement Saving," in Proceedings of the National Tax Association-Tax Institute of America (Columbus: National Tax Association), 178-183.

Gentry, William M., and Joseph Milano, 1994, "Taxes and the Increased Investment in Annuities," mimeo, Duke University Department of Economics.

Gifford, Donald W., 1974, "A Note on Loading Charges for Variable Annuities: Comment," Journal of Risk and Insurance 41: 523-526.

Gilbert, E. Albert, 1948, Insurance and Your Security (New York: Rinehart and Company). 
Greene, Mark R., 1973, "A Note on Loading Charges for Variable Annuities," Journal of Risk and Insurance 40: 473-478.

Greene, Mark R., 1977, Risk and Insurance, 4th Edition (Cincinnati: South-Western Publishers).

Harwood, E. C., and Bion H. Francis, 1942, Life Insurance from the Buyer's Point of View (Cambridge: American Institute for Economic Research).

Hoffman, Arnold J., and John P. Mondejar, 1992, "Pension Funds and Financial Markets, 1950-1989," in John A. Turner and Daniel J. Beller, eds., Trends in Pensions 1992 (Washington: U.S. Government Printing Office).

James, Marquis, 1947, The Metropolitan Life: A Study in Business Growth (New York: Viking Press).

Kotlikoff, Laurence J. and Avia Spivak, 1981, "The Family as an Incomplete Annuities Market," Journal of Political Economy 89, 372-391.

LIMRA International, 1994, U.S. Individual Annuities: Third Quarter 1994 (Hartford: LIMRA International).

Lonkevich, Dan, 1994, "Greenspan's Stance Worries Insurers," Best's Review/Life and Health 95 (November), 51-55.

Maclean, Joseph B., 1962, Life Insurance, 9th Edition (New York: McGraw Hill).

Mitchell, Olivia, James Poterba, and Mark Warshawsky, 1997, "New Evidence on the Money's Worth of Individual Annuities," mimeo, MIT Department of Economics.

Murphy, Ray D., 1939, Sale of Annuities by Governments (New York: Association of Life Insurance Presidents).

Murphy, Ray D., 1950, "Significant Annuity Developments," in David McCahan, ed., Life Insurance Trends at Mid-Century (Philadelphia: University of Pennsylvania Press), 84- 
99.

Pallay, Gary S., 1995, "Outlook Remains Good for Variable Annuities," Best's Review: Life/Health 96 (January), 50-53.

Schultz, Ellen E., 1995, "With Annuities, One Golden Egg Doesn't Mean Snap Up the Carton," Wall Street Journal 5 October 1995, p. R13.

Temporary National Economic Commission. Concentration of Economic Power (Washington:

U.S. Government Printing Office, 1941).

Trieschmann, James and Sandra Gustavson, 1995, Risk Management and Insurance, 9th Edition (Cincinnati, OH: South Western College Publishing).

U.S. General Accounting Office, 1990, Tax Treatment of Life Insurance and Annuity Accrued Interest. (Washington: U.S. General Accounting Office).

U.S. Department of Labor, 1995, Private Pension Plan Bulletin (Washington: U.S. Department of Labor, Office of Research and Economic Analysis).

Variable Annuity Research and Data Service, 1994, The VARDS Report (January).

Warshawsky, Mark, 1988, "Private Annuity Markets in the United States, 1919-1984," Journal of Risk and insurance 40 (September), 518-528. 
43

Table 1: Annuity vs. Life Insurance Payouts (millions of 1994 dollars)

\begin{tabular}{|c|c|c|c|}
\hline Year & Life Insurance Payouts & Annuity Payouts & Ratio (1)/(2 \\
\hline 1940 & 26355 & 1864 & 0.07 \\
\hline 1945 & 20194 & 1779 & 0.08 \\
\hline 1950 & 20947 & 2012 & 0.09 \\
\hline 1955 & 27015 & 2772 & 0.09 \\
\hline 1960 & 36514 & 4158 & 0.10 \\
\hline 1965 & 47630 & 6120 & 0.11 \\
\hline 1966 & 49760 & 6557 & 0.12 \\
\hline 1967 & 51932 & 7095 & 0.12 \\
\hline 1968 & 53827 & 7474 & 0.12 \\
\hline 1969 & 54976 & 7758 & 0.12 \\
\hline 1970 & 54767 & 8102 & 0.13 \\
\hline 1971 & 54384 & 8513 & 0.14 \\
\hline 1972 & 56574 & 9323 & 0.14 \\
\hline 1973 & 57717 & 10130 & 0.15 \\
\hline 1974 & 54450 & 10080 & 0.16 \\
\hline 1975 & 52018 & 10102 & 0.16 \\
\hline 1976 & 52627 & 11517 & 0.18 \\
\hline 1977 & 51868 & 12889 & 0.20 \\
\hline 1978 & 51748 & 13335 & 0.20 \\
\hline 1979 & 50734 & 15418 & 0.23 \\
\hline 1980 & 50118 & 18348 & 0.27 \\
\hline 1981 & 51331 & 19611 & 0.28 \\
\hline 1982 & 54064 & 19692 & 0.27 \\
\hline 1983 & 57021 & 20196 & 0.26 \\
\hline 1984 & 60690 & 25566 & 0.30 \\
\hline 1985 & 62367 & 29300 & 0.32 \\
\hline 1986 & 61710 & 30629 & 0.33 \\
\hline 1987 & 61454 & 31715 & 0.34 \\
\hline 1988 & 60706 & 32173 & 0.35 \\
\hline 1989 & 60777 & 35141 & 0.37 \\
\hline 1990 & 63277 & 36933 & 0.37 \\
\hline 1991 & 59810 & 39838 & 0.40 \\
\hline 1992 & 60733 & 39662 & 0.40 \\
\hline 1993 & 61176 & 41356 & 0.40 \\
\hline
\end{tabular}

Source: American Council on Life Insurance, 1994 Fact Book Page 42. 
Table 2: Life Insurance Annuity Premium Income (millions of 1994 dollars)

\begin{tabular}{|c|c|c|}
\hline Year & Individual Annuity & Group Annuity \\
\hline 1951 & 1209 & 4272 \\
\hline 1952 & 1377 & 4722 \\
\hline 1953 & 1433 & 5152 \\
\hline 1954 & 1296 & 5370 \\
\hline 1955 & 1317 & 5810 \\
\hline 1956 & 1254 & 5796 \\
\hline 1957 & 1177 & 6254 \\
\hline 1958 & 1180 & 6127 \\
\hline 1959 & 1203 & 6411 \\
\hline 1960 & 1268 & 5451 \\
\hline 1961 & 1399 & 5471 \\
\hline 1962 & 1478 & 5785 \\
\hline 1963 & 1871 & 6572 \\
\hline 1964 & 2129 & 7018 \\
\hline 1965 & 2580 & 8060 \\
\hline 1966 & 2756 & 8268 \\
\hline 1967 & 3024 & 8836 \\
\hline 1968 & 3307 & 9448 \\
\hline 1969 & 3455 & 11747 \\
\hline 1970 & 3669 & 10553 \\
\hline 1971 & 4420 & 13559 \\
\hline 1972 & 5176 & 14347 \\
\hline 1973 & 5598 & 17018 \\
\hline 1974 & 5788 & 17486 \\
\hline 1975 & 7343 & 20677 \\
\hline 1976 & 9677 & 26712 \\
\hline 1977 & 11140 & 25505 \\
\hline 1978 & 10131 & 27033 \\
\hline 1979 & 10164 & 26480 \\
\hline 1980 & 11331 & 29035 \\
\hline 1981 & 16788 & 28206 \\
\hline 1982 & 23353 & 29887 \\
\hline 1983 & 20850 & 24629 \\
\hline 1984 & 22418 & 38756 \\
\hline 1985 & 28793 & 45493 \\
\hline 1986 & 35307 & 77861 \\
\hline 1987 & 44039 & 71624 \\
\hline 1988 & 54887 & 74581 \\
\hline 1989 & 59089 & 78444 \\
\hline 1990 & 60845 & 85487 \\
\hline 1991 & 56220 & 78251 \\
\hline 1992 & 64800 & 75309 \\
\hline 1993 & 78957 & 81491 \\
\hline
\end{tabular}

Source: American Council on Life Insurance and author's calculations. 
Table 3: Life Insurance Company Reserves for Annuities and Life Insurance Policies (millions of 1994 dollars)

\begin{tabular}{ccccc}
\hline Year & $\begin{array}{c}\text { Individual } \\
\text { Annuity }\end{array}$ & Group Annuity & $\begin{array}{c}\text { Supplemental } \\
\text { Annuity }\end{array}$ & Life Insurance \\
\hline 1967 & 25508 & 116300 & 15465 & 444469 \\
1968 & 26694 & 121171 & 15384 & 447073 \\
1969 & 25651 & 126128 & 14810 & 444662 \\
1970 & 26564 & 129289 & 14241 & 441238 \\
1971 & 28031 & 139607 & 14299 & 445211 \\
1972 & 30366 & 152373 & 14003 & 455036 \\
1973 & 31671 & 153036 & 13581 & 449880 \\
1974 & 31618 & 147019 & 12562 & 426009 \\
1975 & 34296 & 159786 & 11798 & 413649 \\
1976 & 39999 & 182328 & 11494 & 412735 \\
1977 & 46330 & 190061 & 11167 & 409369 \\
1978 & 52442 & 224436 & 10806 & 404284 \\
1979 & 55363 & 237858 & 10183 & 384389 \\
1980 & 56768 & 252717 & 9386 & 356109 \\
1981 & 63299 & 262653 & 8751 & 337690 \\
1982 & 78378 & 294906 & 8689 & 328539 \\
1983 & 96276 & 330137 & 8745 & 329012 \\
1984 & 109879 & 363388 & 8323 & 322440 \\
1985 & 133646 & 417640 & 8188 & 325066 \\
1986 & 163772 & 480935 & 8494 & 340718 \\
1987 & 203647 & 511994 & 8818 & 360516 \\
1988 & 242971 & 543920 & 9200 & 375954 \\
1989 & 286545 & 566810 & 9495 & 387706 \\
1990 & 319874 & 584803 & 9659 & 395437 \\
1991 & 357231 & 596454 & 9706 & 404841 \\
1992 & 402096 & 591271 & 9912 & 425056 \\
1993 & 450632 & 617236 & 10206 & 447457 \\
\hline$-\cdots---\cdots$ &
\end{tabular}

Source: American Council on Life Insurance and author's calculations. 
46

Table 4: Group Annuities and Private Pension Arrangements, 1978-1993

\begin{tabular}{|c|c|c|c|c|c|c|c|c|}
\hline Year & 1958 & 1963 & 1968 & 1973 & 1978 & 1983 & 1988 & 1993 \\
\hline Group Annuities & 3925 & 5410 & 7310 & 10210 & 15665 & 23165 & 38165 & 44850 \\
\hline $\begin{array}{l}\text { Terminal Funded } \\
\text { Group Plans }\end{array}$ & & 290 & 95 & 200 & 285 & 1740 & 2065 & \\
\hline $\begin{array}{l}\text { Individual Policy } \\
\text { Pension Trusts }\end{array}$ & 605 & 755 & 1100 & 1705 & 1955 & 1880 & 1950 & 1735 \\
\hline Keogh Plans & & & 295 & 465 & 495 & 435 & 320 & \\
\hline $\begin{array}{l}\text { Tax-Sheltered } \\
\text { Annuities }\end{array}$ & & & & 675 & 1400 & 2455 & 4255 & 5805 \\
\hline IRAs & & & & & 960 & 2630 & 5085 & 4710 \\
\hline Other & 395 & 515 & 430 & 645 & 970 & 1515 & 2430 & 1195 \\
\hline TOTAL & 4925 & $6710^{*}$ & 9130 & 13625 & 21615 & 32425 & 54060 & 60680 \\
\hline
\end{tabular}

Source: Author's tabulations from various issues of Life Insurance Fact Book. Note that 1963 data are for 1964 at this date. Each entry shows the number of individuals in thousands) covered in group annuity contracts of various types. 
47

Table 5: Trends in Pension Plans, Participants, and Contributions

\begin{tabular}{|c|c|c|c|}
\hline Year & Plans & Participants & Contributions \\
\hline \multicolumn{4}{|c|}{ Defined Contribution Plans } \\
\hline 1975 & 207.7 & 11.5 & 29.5 \\
\hline 1976 & 246.0 & 13.5 & 30.9 \\
\hline 1977 & 281.0 & 15.2 & 32.5 \\
\hline 1978 & 314.6 & 16.3 & 35.0 \\
\hline 1979 & 331.4 & 18.3 & 35.4 \\
\hline 1980 & 340.8 & 19.9 & 35.4 \\
\hline 1981 & 378.3 & 21.7 & 38.7 \\
\hline 1982 & 419.5 & 24.6 & 40.0 \\
\hline 1983 & 426.6 & 29.1 & 44.9 \\
\hline 1984 & 435.4 & 32.9 & 51.8 \\
\hline 1985 & 462.0 & 35.0 & 61.3 \\
\hline 1986 & 545.0 & 36.7 & 66.0 \\
\hline 1987 & 570.0 & 38.3 & 66.0 \\
\hline 1988 & 584.0 & 37.0 & 68.0 \\
\hline 1989 & 599.0 & 36.5 & 73.2 \\
\hline 1990 & 599.2 & 38.1 & 71.9 \\
\hline 1991 & 597.5 & 38.6 & 73.7 \\
\hline \multicolumn{4}{|c|}{ Defined Benefit Plans } \\
\hline 1975 & 103.3 & 33.0 & 55.8 \\
\hline 1976 & 114.0 & 34.2 & 62.1 \\
\hline 1977 & 121.7 & 35.0 & 63.8 \\
\hline 1978 & 128.4 & 36.1 & 52.5 \\
\hline 1979 & 139.5 & 36.8 & 69.3 \\
\hline 1980 & 148.1 & 38.0 & 64.1 \\
\hline 1981 & 167.3 & 38.9 & 64.1 \\
\hline 1982 & 175.0 & 38.6 & 62.2 \\
\hline 1983 & 175.1 & 40.0 & 57.6 \\
\hline 1984 & 168.0 & 41.0 & 56.3 \\
\hline 1985 & 170.2 & 39.7 & 48.4 \\
\hline 1986 & 172.6 & 40.0 & 37.6 \\
\hline 1987 & 163.1 & 40.0 & 32.5 \\
\hline 1988 & 146.0 & 40.7 & 27.6 \\
\hline 1989 & 132.5 & 40.0 & 24.9 \\
\hline 1990 & 113.1 & 38.8 & 21.8 \\
\hline 1991 & 101.8 & 39.0 & 27.4 \\
\hline
\end{tabular}

Note: The number of plans is measured in thousands, participants in millions, and contributions in billions of 1989 dollars, converted from current dollars using the Consumer Price Index. Data are drawn from U.S. Department of Labor (1995). 
48

Table 6: Individual Annuities in Force 1977-1993

\begin{tabular}{|c|c|c|c|c|}
\hline & \multicolumn{2}{|c|}{$\begin{array}{c}\text { Number of Annuity Policies } \\
\text { Fixed Variable }\end{array}$} & \multicolumn{2}{|c|}{ Annuity Premium Payments } \\
\hline 1977 & 3.68 & 0.67 & & \\
\hline 1978 & 4.24 & 0.69 & & \\
\hline 1979 & 4.49 & 0.72 & & \\
\hline 1980 & 5.40 & 0.76 & 9.0 & 1.8 \\
\hline 1981 & 6.11 & 0.80 & 14.7 & 1.6 \\
\hline 1982 & 7.69 & 0.90 & 20.0 & 3.1 \\
\hline 1983 & 8.55 & 1.03 & 17.9 & 4.5 \\
\hline 1984 & 9.47 & 1.20 & 20.0 & 2.9 \\
\hline 1985 & 10.00 & 1.46 & 26.2 & 4.1 \\
\hline 1986 & 10.88 & 1.91 & 31.1 & 4.1 \\
\hline 1987 & 12.07 & 2.29 & 37.8 & 6.5 \\
\hline 1988 & 13.34 & 2.47 & 48.9 & 6.3 \\
\hline 1989 & 14.16 & 2.73 & 51.4 & 7.2 \\
\hline 1990 & 16.31 & 2.91 & 54.4 & 6.8 \\
\hline 1991 & 17.34 & 2.84 & 47.9 & 8.7 \\
\hline 1992 & 19.29 & 3.93 & 48.6 & 16.9 \\
\hline 1993 & 21.50 & 5.25 & 41.0 & 30.8 \\
\hline 1994 & --- & ---- & 55.0 & 40.0 \\
\hline
\end{tabular}

Source: Columns 1 and 2, American Council on Life Insurance. Statistics exclude supplementary contracts. Columns 3 and 4, Bernstein Research. Values for number of annuity policies are in millions, premium values are in billions of 1994 dollars. 
49

Table 7: Life Insurance Company Variable Annuity Reserves (millions of 1994 dollars)

\begin{tabular}{|c|c|c|}
\hline Year & $\begin{array}{r}\text { Group } \\
\text { Policies }\end{array}$ & $\begin{array}{l}\text { Individual } \\
\text { Policies }\end{array}$ \\
\hline $\begin{array}{l}1967 \\
1968 \\
1969 \\
1970 \\
1971 \\
1972 \\
1973 \\
1974 \\
1975 \\
1976 \\
1977 \\
1978 \\
1979 \\
1980 \\
1981 \\
1982 \\
1983 \\
1984 \\
1985 \\
1986 \\
1987 \\
1988 \\
1989 \\
1990 \\
1991 \\
1992 \\
1993\end{array}$ & $\begin{array}{r}5199 \\
7965 \\
9274 \\
9223 \\
11069 \\
12790 \\
13400 \\
12303 \\
15911 \\
18184 \\
19042 \\
18230 \\
15976 \\
17920 \\
17683 \\
17547 \\
19617 \\
22449 \\
25589 \\
30166 \\
30726 \\
33619 \\
37275 \\
38239 \\
41170 \\
43239 \\
56052\end{array}$ & $\begin{array}{r}71 \\
158 \\
319 \\
581 \\
1311 \\
2239 \\
2849 \\
2960 \\
4377 \\
5958 \\
6431 \\
7094 \\
8144 \\
8673 \\
9445 \\
10481 \\
13252 \\
14370 \\
20559 \\
28105 \\
35612 \\
41469 \\
49867 \\
54141 \\
57984 \\
79512 \\
114534\end{array}$ \\
\hline
\end{tabular}

Source: American Council on Life Insurance and author's calculations. 
$\underline{50}$

Table 8: Comparison of Rates of Return on Tax-Deferred and Taxable Investments

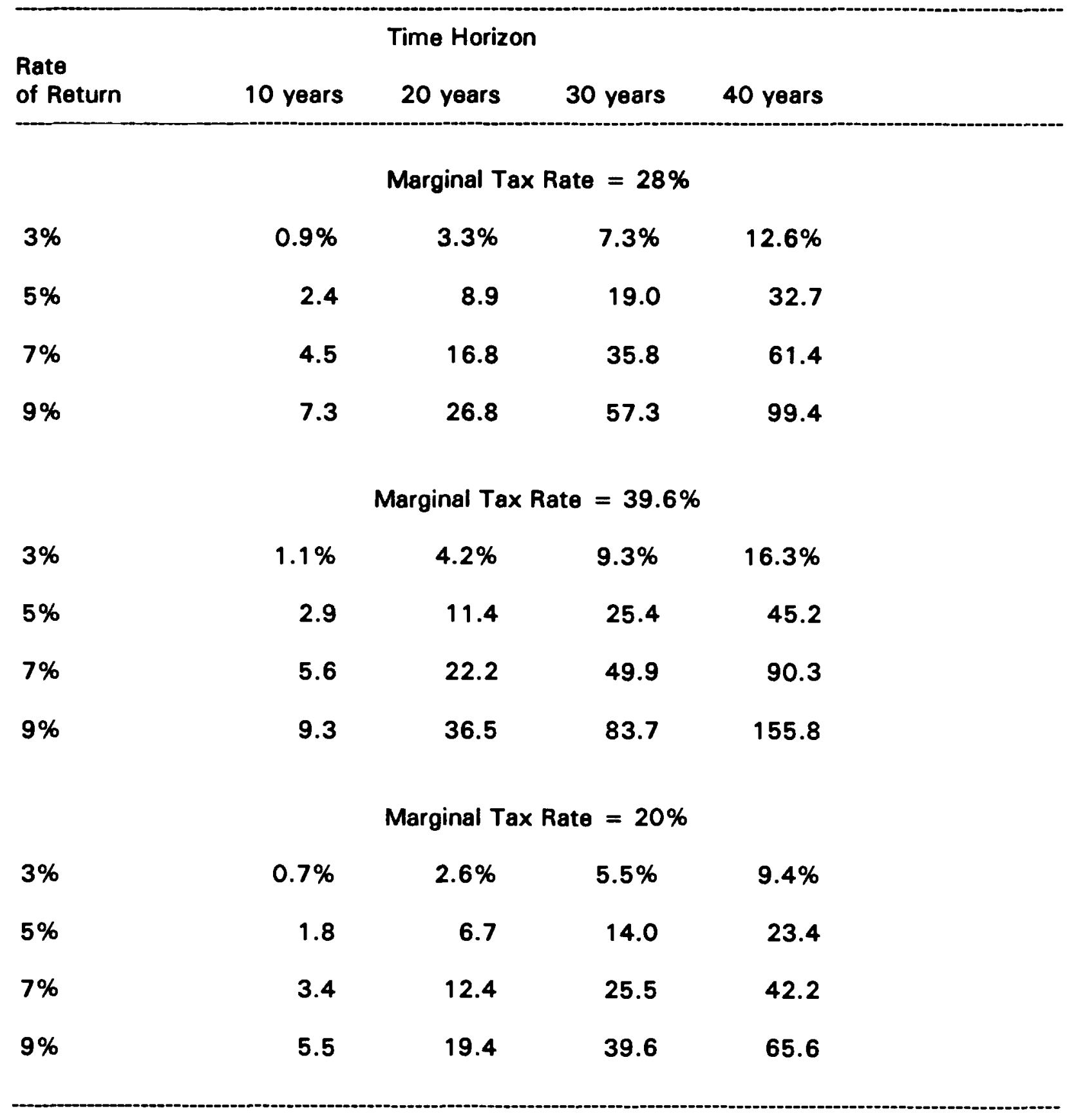

Source: Author's calculations. Each entry shows the value of $100 *\left(1+(1-\tau)\left(e^{r T}-1\right)\right) / e^{r(1-r T T}$. The numerator reflects the value of an asset that accumulates at a pretax rate of return $r$ for a period of $T$ years, and is taxed at maturity at a rate ron the difference between its maturity value and initial investment. The denominator is thevalue of an asset that grows at an aftertax rate of return $r(1-T)$ for $T$ years. 